\title{
Growth and carcass characteristics of different crosses of broiler chickens reared under an alternative system
}

\section{Características de crescimento e carcaça de diferentes cruzamentos de frangos criados em sistema alternativo}

\author{
Fábio Loures Cruz ${ }^{1 *}$; Lorena Katheryne Vieira Saraiva ${ }^{2}$; Grace Ellen Silva \\ Tatiane Mendonça Nogueira ${ }^{4}$; Ana Paula Silva ${ }^{5}$ Peter Bitencourt Faria ${ }^{6}$
}

\begin{abstract}
This study aimed to assess the effect of different breeds and crosses of broiler chickens and sex on growth, carcass characteristics, and tissue composition. The experimental design was a completely randomized design in a $6 \times 2$ factorial scheme, with six genotypes (New Hampshire - NHS, Jersey Black Giant - JBG, Rodhe Island Red - RIR, Indigenous Giant - IG, and the hybrids IG $\times$ NHS and IG $\times$ JBG) and two sexes (male and female). Each treatment was composed of five replications with three broiler chickens, totaling 180 broiler chickens. Zootechnical performance and growth were assessed through the Gompertz equation parameters. After slaughtering at 105 days, the characteristics of carcass and main cuts were determined by means of weight, yield, and proportion of tissue constituents (meat, bone, and skin). Regarding the Gompertz equation parameters, the genotype NHS presented a higher growth potential. Males presented higher live weight and carcass weights, except for IG. No difference was observed between genotypes and sexes $(\mathrm{P}>0.05)$ for carcass yield. The genotype JBG presented the highest average for breast yield (24.4\%). Males presented the highest average for leg yield (30.5\%). The genotype IG presented the highest value of breast meat yield $(71.2 \%)$, being similar to the genotypes from the crosses IG $\times$ NHS, and IG $\times$ JBG ( 68.9 and $68.3 \%$, respectively). For meat to breastbone ratio, the genotype IG presented the highest value (3.4) and, considering the sex, females presented a higher average (3.2) for this characteristic. Regarding the proportion of leg meat, an effect was observed for genotype and sex $(\mathrm{P}<0.05)$ with the highest values observed for the hybrid IG $\times \mathrm{JBG}$ and females $(66.3$ and $66.0 \%$, respectively). For meat to leg bone ratio, the genotypes NHS, JBG, RIR, and IG $\times$ NHS presented the highest values $(2.6,2.7,2.6$, and 2.6 , respectively), with females presenting the highest value $(\mathrm{P}<0.05)(2.7)$. The genotypes IG, IG $\times$ NHS and IG $\times$ JBG presented the best growth and carcass characteristics, being recommended to be reared under an alternative system. Females presented the highest breast yield and, proportionally, the highest amount of leg meat, which are important attributes in a chicken meat production system.
\end{abstract}

Key words: Breeds. Carcass yield. Gender. Indigenous Giant. Tissue constituents.

\footnotetext{
${ }^{1}$ Me. em Ciências Veterinárias, Discente de Doutorado, Universidade Federal de Lavras, UFLA, Lavras, MG, Brasil. E-mail: fabiolourescruz@gmail.com

${ }^{2}$ Médica Veterinária, Discente de Mestrado, Universidade Federal de Minas Gerais, UFMG, Montes Claros, Brasil. E-mail: lorenakvs@hotmail.com

${ }^{3}$ Discente, Curso de Graduação em Medicina Veterinária, UFLA, Lavras, MG, Brasil. E-mail: grace_ellens@hotmail.com

${ }^{4}$ M.e, em Ciências Veterinárias, UFLA, Lavras, MG, Brasil. E-mail: tati.mn@hotmail.com

5 Médica Veterinária, E-mail: anysilvas27@hotmail.com

${ }^{6}$ Prof. Adjunto, UFLA, Lavras, MG, Brasil. E-mail: peterbfvet@yahoo.com.br

* Author for correspondence
} 


\section{Resumo}

Objetivou-se avaliar o efeito de diferentes raças e cruzamentos de frangos e do sexo sobre as características de crescimento, carcaça e composição dos tecidos. O delineamento foi inteiramente casualizado disposto em esquema fatorial (6x2), sendo seis genótipos (New Hampshire - NHS; Gigante Negra de Jersey - GNJ; Rodhe Island Red - RIR; Índio Gigante - IG; cruzamento entre as raçasIG e NHS - IG x NHS e entre IG e GNJ - IG x GNJ) e dois sexos (macho e fêmea), com cinco repetições e três aves por repetição, totalizando 180 aves. Foi avaliado o desempenho zootécnico e o crescimento, através de parâmetros da equação de gompertz. Após o abate, que ocorreu aos 105 dias, foram determinadas as características de carcaça e dos principais cortes através do peso, do rendimento e da proporção dos constituentes teciduais (carne, osso e pele). Com relação aos parâmetros da equação de gompertz, as aves da raça NHS apresentaram maior potencial de crescimento. Os machos apresentaram médias superiores de peso vivo e de carcaça, exceto para o genótipo IG. Não houve diferença entre genótipos e sexos $(\mathrm{P}>0,05)$ para o rendimento de carcaça. $\mathrm{O}$ genótipo GNJ apresentou a maior média de rendimento de peito $(24,4 \%)$. Para o rendimento de perna, os machos apresentaram a maior média $(30,5 \%)$. A raça IG apresentou maior valor de rendimento de carne do peito $(71,2 \%)$, sendo semelhante aos genótipos oriundos dos cruzamentos, IG x NHS e IG x GNJ (68,9 e 68,3 \%, respectivamente). Para a relação carne/osso do peito, as aves da raça IG apresentaram o maior valor $(3,4)$ e, com relação ao sexo, as fêmeas apresentaram média superior $(3,2)$. Com relação à proporção de carne da perna, houve efeito do genótipo e do sexo $(\mathrm{P}<0,05)$, sendo que o genótipo IG x GNJ e as fêmeas apresentaram maiores valores (66,3 e 66,0 \%, respectivamente). Para a relação carne/osso da perna, os genótipos NHS, GNJ, RIR e IG x NHS apresentaram os maiores valores (2,6, 2,7, 2,6 e 2,6, respectivamente). As fêmeas apresentaram maior valor $(\mathrm{P}<0,05)$ para esta variável $(2,7)$. Os genótipos IG, IG x NHS e IG x GNJ apresentaram as melhores características de crescimento e de carcaça sendo preconizadas para a produção em sistema alternativo. As fêmeas apresentaram maior rendimento de peito e proporcionalmente maior quantidade de carne na perna, que são atributos importantes em um sistema de produção de carne de frango.

Palavras-chave: Constituintes teciduais. Índio Gigante. Raças. Rendimento de carcaça. Sexo.

\section{Introduction}

In recent years, there has been a significant growth of alternative systems for rearing broiler chickens due to the modern demand of consumers for natural products with more pronounced flavors. This tendency was accompanied by an evolution in the genetic area, with the emergence of new strains of free-range broiler chickens that present rusticity and good productive indices (DEL CASTILHO et al., 2013).

For profitability of this alternative poultry activity, the factors interfering with the most important carcass parameters for the market need to be taken into consideration, such as carcass, breast, and thigh yields, which are the most valued cuts and are directly influenced by genetics and sex (FARIA et al., 2010). Differences between sexes can occur due to the effect of sexual dimorphism related to the production of androgen hormones, which are responsible for muscle anabolism (DEL CASTILHO et al., 2013). The choice of genetics is essential for the economic return of poultry activity and production planning since the growth rate of bird can influence yield and carcass composition (SARICA et al., 2014; VELOSO et al., 2014).

In this context, small and medium farmers have performed crosses between birds of different breeds and strains looking for characteristics such as rusticity, precocity, and mainly good yield indices of carcass and noble cuts for rearing broilers under extensive systems. However, the knowledge of the main characteristics of production, growth, and carcass is necessary for breed selection to be used in crosses of broiler chickens. Thus, the aim of this study was to assess the effect of different genotypes and sex on growth, performance, carcass characteristics, and tissue composition of broiler chickens recommended to be reared under an alternative system. 


\section{Material and Methods}

The experiment was conducted in the Poultry Sector of the Department of Animal Science of the Federal University of Lavras (UFLA), Lavras, MG, Brazil, from July to October 2014. Breeds of broiler chickens used under alternative systems were selected for the experiment. The experimental design was a completely randomized design arranged in a factorial scheme $(6 \times 2)$ with six genotypes (New Hampshire - NHS, Jersey Black Giant - JBG, Rodhe Island Red - RIR, Indigenous Giant - IG, F1 generation resulted from the cross between Indigenous Giant roosters and New Hampshire fowls - IG $\times$ NHS, and F1 generation resulted from the cross between Indigenous Giant roosters and Jersey Black Giant fowls $-\mathrm{IG} \times \mathrm{JBG}$ ) and two sexes (male and female), totaling 12 treatments. Each treatment consisted of five replications with three broiler chickens, totaling 15 broiler chickens per treatment and a total 180 broiler chickens (90 males and 90 females).

The diet for free-range broiler chickens was composed of three diet formulations considering their rearing phases: initial (1 to 30 days) without access to the grazing area, growth (31 to 55 days), and final (56 to 105 days) (Table 1). Thirty broiler chickens of each genotype were raised in an experimental unit of $90 \mathrm{~m}^{2}$ with access to grazing, food, and water ad libitum.

Table 1. Composition and calculated values of experimental diets for free-range broiler chickens according to the rearing phase and age range in days.

\begin{tabular}{lccc}
\hline Ingredient (kg) & Starter (1 to 30) & Growing (31 to 55) & (56 to 105) \\
\hline Corn & 57,91 & 63,69 & 68,54 \\
Soybean Meal & 31,48 & 25,94 & 24,03 \\
Wheat Meal & 6,81 & 7,01 & 4,23 \\
Bicalcium Phosphate & 1,59 & 1,36 & 1,31 \\
Limestone & 1,35 & 1,26 & 0,33 \\
Common Salt & 0,38 & 0,35 & 0,10 \\
Mineral Premix ${ }^{1}$ & 0,10 & 0,10 & 0,10 \\
Premix Vitamin & 0,10 & 0,10 & 0,13 \\
DL-Methionine 99\% & 0,14 & \\
L-Lisine 78\% & 0,20 & & 0,05 \\
Choline Chloride 60\% & 0,03 & 0,05 & 100 \\
Total (kg) & 100 & 100 & 17,00 \\
Calculated values & & 18,00 & 2940 \\
\hline Crude protein (\%) & 20,00 & 2870 & 0,85 \\
ME ${ }^{3}$ (kcal/kg) & 2800 & 0,90 & 0,35 \\
Calcium (\%) & 1,00 & 0,37 & 0,15 \\
Available phosphorus (\%) & 0,42 & 0,16 & 0,61 \\
Sodium (\%) & 0,17 & 0,64 & 0,76 \\
digM + C (\%) & 0,74 & 0,81 & 0,18 \\
Digestible Lysine (\%) & 0,96 & 0,19 & 2,86 \\
Digestible tryptophan (\%) & 0,22 & 3,14 & \\
Crude fiber (\%) & 3,32 & 0072,850 \\
\hline
\end{tabular}

${ }^{1}$ Mineral premix: Manganese, $75000 \mathrm{mg}$; zinc, $70000 \mathrm{mg}$; iron, $50000 \mathrm{mg}$; copper, $8500 \mathrm{mg}$; iodine, $1500 \mathrm{mg}$; cobalt, $200 \mathrm{mg}$. ${ }^{2}$ Vitamin premix: Vitamin A, 7000000 IU; vitamin D3, 2100000 IU; vitamin E, $50000 \mathrm{mg}$; vitamin K3, $2000 \mathrm{mg}$; vitamin B1, 2000 mg; vitamin B2, $4000 \mathrm{mg}$; vitamin B6, $3000 \mathrm{mg}$; vitamin B12, $3000 \mathrm{mg}$; niacin, $39800 \mathrm{mg}$; pantothenic acid, $15620 \mathrm{mg}$; folic acid, $1000 \mathrm{mg}$; selenium, $200 \mathrm{mg}$; biotin, $100 \mathrm{mg}$; antioxidant, $100000 \mathrm{mg} .{ }^{3} \mathrm{ME}$ : Metabolizable energy. ${ }^{4} \mathrm{M}+\mathrm{Cdig}$ : methionine plus digestible cystine. 
For the growth study, the parameters of the Gompertz equation were determined. The assessments of weight gain, feed intake, and feed conversion were performed according to the methodology of Del Castilho et al. (2013). Data acquisition was only descriptive since the rearing of broiler chickens was conducted in separate pickets according to the genotypes.

Broiler chickens were weighed, identified, fasted for 8 hours, and slaughtered by cervical dislocation followed by bleeding at 105 days of age. After evisceration, carcasses were individually packed in plastic bags and cooled at $5{ }^{\circ} \mathrm{C}$ for a period of 24 hours, following the distribution of treatments and repetitions. Subsequently, these carcasses were weighed for calculating the carcass and cut yields, as well as tissue composition, as Faria et al. (2011).

The data were analyzed by using the statistical program SISVAR ${ }^{\circledR}$. The variables with responses of significant effects in the analysis of variance for treatments and/or interactions were submitted to the Tukey's test at 5\% significance. All procedures described were approved by the Ethics Committee on Animal Use (CEUA) of the Federal University of Lavras (protocol number 017/14).

\section{Results and Discussion}

Broiler chickens from the F1 generation from the crosses between Indigenous Giant (IG) and Jersey
Black Giant $(\mathrm{JBG})(\mathrm{IG} \times \mathrm{JBG})$ presented higher estimated values of live weight at maturity $\left(\mathrm{W}_{\mathrm{m}}\right)$ (Table 2). The highest value of maturity rate (b) was observed for the genotype New Hampshire (NHS), indicating that this genotype presents a higher daily weight gain and hence a higher growth potential (Table 2). In addition, NHS presented the lowest age for the maximum growth rate $\left(\mathrm{T}^{*}\right)$, evidencing their higher precocity. As the age increases, growth rate slows and the moment at which the acceleration pattern changes characterizes the inflection point, corresponding to the $\mathrm{T}^{*}$ value (KESSLER, 2000). Parameter values of the Gompertz equation of all genotypes presented a high reliability, with $\mathrm{R}^{2}$ values above 0.98 (Table 2).

A numerical difference was observed between genotypes for weight gain, feed intake, and feed conversion (Table 2). Higher values of weight gain were observed for broiler chickens from the genotypes NHS, IG $\times$ NHS, and IG $\times$ JBG. These results show that crossbreeding provided offspring with higher potentials of weight gain when compared to purebred birds used at crosses, which is mainly due to the hybrid vigor effect. In addition to being considered pure, the genotype NHS presents a great potential for lean tissue deposition in the carcass, which gives it a higher weight gain rate, being used in breeding programs that originated many current hybrids of broiler chickens (ALBINO et al., 2014).

Table 2. Parameters of performance and Gompertz equations for live weight of chicken broilers of different breeds and crosses.

\begin{tabular}{|c|c|c|c|c|c|c|}
\hline \multirow{2}{*}{ Parameters } & \multicolumn{6}{|c|}{ Genotypes } \\
\hline & NHS & JBG & RIR & IG & IG $x$ NHS & IG $\times$ JBG \\
\hline $\mathrm{P}_{\mathrm{m}}(\mathrm{g})^{(1)(\mathrm{a})}$ & 2637 & 2832 & 2343 & 2800 & 3211 & 3620 \\
\hline b (per day) ${ }^{(2)(a)}$ & 0,0222 & 0,0175 & 0,0201 & 0,0205 & 0,0212 & 0,0197 \\
\hline $\mathrm{T}^{*}(\text { day })^{(3)(a)}$ & 61 & 86 & 63 & 70 & 73 & 79 \\
\hline $\mathrm{R}^{2}$ & 0,9955 & 0,9878 & 0,9887 & 0,9993 & 0,9989 & 0,9998 \\
\hline Weight Gain (g/ave) ${ }^{(\mathrm{al})}$ & 144,6 & 138,4 & 126,0 & 123,1 & 149,1 & 143,1 \\
\hline feed intake (g/ave) ${ }^{(\mathrm{a} 2)}$ & 652,4 & 649,3 & 611,5 & 632,0 & 637,7 & 629,9 \\
\hline feed conversion ${ }^{(\mathrm{a} 2)}$ & 4,1 & 3,8 & 3,6 & 4,1 & 4,0 & 3,5 \\
\hline
\end{tabular}

(1)Weight at maturity; (2) maturity rate; ${ }^{(3)}$ age at which growth rate is maximal; Gompertz equation: $\mathrm{P}_{t}=\mathrm{P}_{\mathrm{m}} \times \exp (-\exp (-\mathrm{b} \times($ age t))); ${ }^{(a)}$ Descriptive data; ${ }^{(1)}$ Period: 1 to 105 days; ${ }^{(2)}$ Period: 36 to 105 days. Namely: NHS - New Hampshire; JBG - Jersey Black Giant; RIR - Rodhe Island Red; IG - Indigenous Giant; IG $\times$ NHS - F1 generation resulted from the cross between Indigenous Giant and New Hampshire; IG $\times$ JBG - F1 generation resulted from the cross between Indigenous Giant and Jersey Black Giant. 
Broiler chickens from the genotypes NHS and JBG presented the highest feed intake (Table 2) and, in general, a great potential of weight gain and deposition of lean tissue in the carcass (ALBINO et al., 2014). According to Santos et al. (2005), broiler chickens with genetic characteristics that provide higher growth rates, i.e. higher potentials of weight gain, present a higher feed intake due to their higher nutritional requirements to express their genetic potential.

The best values of feed conversion were observed for broiler chickens from the genotype Rodhe Island Red (RIR) and those from crosses between IG and JBG $(\mathrm{IG} \times \mathrm{JBG})($ Table 2$)$. In general, acceleratedgrowth broiler chickens are more efficient at converting ingested food into body weight gain than slow-growing broiler chickens (GONZALES et al., 1998). However, broiler chickens with greater potential of weight gains such as those from the genotypes NHS and JBG presented worse feed conversion rates mainly due to higher feed intake values. Moreover, broiler chickens from crosses $(\mathrm{IG} \times \mathrm{NHS}$ and $\mathrm{IG} \times \mathrm{JBG})$ presented better values of feed conversion when compared to purebred birds used at crosses such as IG, NHS, and JBG, which indicates a positive effect of crossing on the efficiency in converting the ingested food into weight gain.

An interaction between sex and genotype was observed for live weight, carcass, and legs (Table $3)$. In this case, males presented the highest averages for all genotypes, except for the genotype IG, which did not show difference between sexes (Table 4). Among males, the genotypes RIR and IG presented the lowest averages for these variables whereas this behavior was observed for the genotype RIR among females. In addition, the results were similar among the other genetic groups.

In general, this behavior is related to the sexual dimorphism (GONZALES; SARTORI, 2002; DEL CASTILHO et al., 2013), in which males present a higher growth potential due to their capacity of muscular deposition (FARIA et al., 2011; MITROVIC et al., 2011). Because the genotype
RIR has better characteristics for egg production, they have lighter carcasses whereas broiler chickens from the genotype IG present later sexual maturity, which may have led to the lowest values of these variables since their gonads were not yet developed (ABCIG, 2016). Higher values of live weight and carcass are characteristic of broiler chicken strains with higher growth potentials, which present a higher meat production capacity (SARICA et al., 2014; VELOSO et al., 2014).

No effect of genotype and sex were observed for carcass yield values (Table 3 ). This result is regardless of genetic potential or sex category; and it would be related to the proportional growth rate between broiler chickens of the different tissues and organs (FARIA et al., 2010; MITROVIC et al., 2011; VELOSO et al., 2014).

Male broiler chickens from the genotypes NHS, RIR, IG $\times$ NHS, and IG $\times$ JBG and female broiler chickens from the genotypes JBG and IG showed higher average values of breast weight. Among males, the genotypes RIR and IG presented the lowest average values of breast weight whereas, among females, the genotypes NHS and RIR presented the lowest values (Table 4). In general, broiler chickens from genotypes with a lower degree of breeding for meat production, such as RIR and IG, tend to show a less development of noble parts of the carcass, such as the breast.

The genotype JBG presented the highest average of breast yield when compared to NHS, however similar to the other genotypes (Table 4). These results indicated that the crosses provided individuals with similar characteristics of breast yield, which is associated with growth rate, muscle development, and proportion of red/white fibers (MADEIRA et al., 2006; FARIA et al., 2010; MIKULSKI et al., 2011; SARICA et al., 2014).

In general, females presented the highest average values of breast yield, while males presented the highest values of leg yields (Table 3). These results would be related to the effect of sexual dimorphism, as found in other studies (FARIA et al., 2011; DEL CASTILHO et al., 2013; SARICA et al., 2014). 
Table 3. Parameters of carcass and cuts of broiler chickens reared under an alternative system.

\begin{tabular}{|c|c|c|c|c|c|c|c|}
\hline \multirow{2}{*}{ Variable } & \multirow{2}{*}{$\begin{array}{l}\text { Average } \\
\text { Overall }\end{array}$} & \multicolumn{2}{|c|}{ Sex } & \multicolumn{3}{|c|}{$\mathbf{P}^{(1)}$} & \multirow{2}{*}{$\begin{array}{l}C V^{(2)} \\
(\%)\end{array}$} \\
\hline & & Male & Female & Genotype (G) & Sex (S) & SxG & \\
\hline Live Weight (kg) & 1,8 & $2,1 \mathrm{a}$ & $1,6 \mathrm{~b}$ & $0,001^{*}$ & $0,001^{*}$ & $0,015^{*}$ & 8,1 \\
\hline Carcass Weight $(\mathrm{Kg})$ & 1,4 & $1,5 \mathrm{a}$ & $1,2 \mathrm{~b}$ & $0,001^{*}$ & $0,001^{*}$ & $0,007^{*}$ & 10,9 \\
\hline$C Y^{(3)}(\%)$ & 75,6 & $73,8 \mathrm{a}$ & $75,2 \mathrm{a}$ & $0,506^{\mathrm{ns}}$ & $0,318^{\text {ns }}$ & $0,306^{\mathrm{ns}}$ & 7,2 \\
\hline Breast (g) & 306,6 & $327,1 b$ & $302,9 a$ & $0,001^{*}$ & $0,001^{*}$ & $0,001^{*}$ & 10,7 \\
\hline Breast (\%) & 22,4 & $21,6 b$ & $23,8 \mathrm{a}$ & $0,007^{*}$ & $0,001^{*}$ & $0,284^{\mathrm{ns}}$ & 8,0 \\
\hline Breast Meat (g) & 207,1 & $220,9 a$ & $193,2 b$ & $0,001^{*}$ & $0,001^{*}$ & $0,018^{*}$ & 13,1 \\
\hline Breast Meat (\%) & 67,8 & $67,2 \mathrm{a}$ & $68,4 \mathrm{a}$ & $0,001^{*}$ & $0,117^{\mathrm{ns}}$ & $0,167^{\mathrm{ns}}$ & 4,2 \\
\hline Breast Skin (g) & 29,0 & $29,7 \mathrm{a}$ & $27,6 \mathrm{a}$ & $0,001^{*}$ & $0,065^{\mathrm{ns}}$ & $0,830^{\mathrm{ns}}$ & 18,9 \\
\hline Breast Skin $(\%)$ & 9,6 & $9,2 \mathrm{~b}$ & $10,0 \mathrm{a}$ & $0,001^{*}$ & $0,015^{*}$ & $0,022^{*}$ & 12,7 \\
\hline Breast Bone (g) & 68,5 & $76,7 \mathrm{a}$ & $60,4 b$ & $0,004^{*}$ & $0,001^{*}$ & $0,684^{\mathrm{ns}}$ & 14,6 \\
\hline Breast Bone (\%) & 22,6 & $23,6 a$ & $21,6 b$ & $0,252^{\mathrm{ns}}$ & $0,008^{*}$ & $0,773^{\text {ns }}$ & 12,2 \\
\hline Breast meat/bone & 3,2 & $2,9 b$ & $3,2 \mathrm{a}$ & $0,018^{*}$ & $0,013^{*}$ & $0,353^{\text {ns }}$ & 15,1 \\
\hline $\operatorname{Leg}(\mathrm{g})$ & 413,3 & $474,5 \mathrm{a}$ & $352,1 b$ & $0,001^{*}$ & $0,001^{*}$ & $0,007^{*}$ & 9,5 \\
\hline Leg $(\%)$ & 29,9 & $30,5 \mathrm{a}$ & $29,3 b$ & $0,129^{\text {ns }}$ & $0,001^{*}$ & $0,186^{\mathrm{ns}}$ & 4,6 \\
\hline Leg Meat (g) & 262,6 & $300,0 \mathrm{a}$ & $227,4 b$ & $0,001^{*}$ & $0,001^{*}$ & $0,005^{*}$ & 11,5 \\
\hline Leg Meat (\%) & 65,0 & $64,4 b$ & $66,0 \mathrm{a}$ & $0,014^{*}$ & $0,001^{*}$ & $0,639^{\mathrm{ns}}$ & 2,6 \\
\hline Leg Skin (g) & 35,3 & $38,7 \mathrm{~b}$ & $31,9 a$ & $0,001^{*}$ & $0,001^{*}$ & $0,217^{\mathrm{ns}}$ & 13,4 \\
\hline Leg Skin $(\%)$ & 8,9 & $8,3 \mathrm{~b}$ & $9,4 \mathrm{a}$ & $0,001^{*}$ & $0,001^{*}$ & $0,021^{*}$ & 7,2 \\
\hline Leg Bone (g) & 106,1 & $126,3 \mathrm{a}$ & $85,2 b$ & $0,001^{*}$ & $0,001^{*}$ & $0,131^{\text {ns }}$ & 12,4 \\
\hline Leg Bone (\%) & 26,1 & $27,3 \mathrm{a}$ & $24,6 b$ & $0,001^{*}$ & $0,001^{*}$ & $0,700^{\text {ns }}$ & 6,1 \\
\hline Leg meat/bone & 2,6 & $2,4 \mathrm{~b}$ & $2,7 \mathrm{a}$ & $0,002^{*}$ & $0,001^{*}$ & $0,858^{\mathrm{ns}}$ & 8,9 \\
\hline Wing (g) & 166,8 & $186,8 \mathrm{a}$ & $146,8 b$ & $0,001^{*}$ & $0,001^{*}$ & $0,005^{*}$ & 9,2 \\
\hline Wing (\%) & 12,3 & $12,41 \mathrm{a}$ & $12,25 \mathrm{a}$ & $0,175^{\text {ns }}$ & $0,539^{\mathrm{ns}}$ & $0,229^{\text {ns }}$ & 8,1 \\
\hline Back (g) & 238,4 & $268,6 a$ & $208,1 b$ & $0,001^{*}$ & $0,001^{*}$ & $0,001^{*}$ & 10,8 \\
\hline Back (\%) & 17,5 & $17,7 \mathrm{a}$ & $17,3 \mathrm{a}$ & $0,279^{\text {ns }}$ & $0,326^{\text {ns }}$ & $0,296^{\mathrm{ns}}$ & 9,6 \\
\hline $\mathrm{EV}^{(4)}(\mathrm{g})$ & 87,95 & $97,6 \mathrm{a}$ & $78,3 b$ & $0,336^{\text {ns }}$ & $0,001^{*}$ & $0,043^{*}$ & 7,4 \\
\hline $\mathrm{EV}^{(4)}(\%)$ & 6,6 & $6,5 \mathrm{a}$ & $6,6^{\mathrm{a}}$ & $0,001^{*}$ & $0,724^{\mathrm{ns}}$ & $0,060^{\mathrm{ns}}$ & 9,6 \\
\hline $\mathrm{AF}^{(5)}(\mathrm{g})$ & 15,2 & $13,8 \mathrm{a}$ & $16,5 \mathrm{a}$ & $0,001^{*}$ & $0,053^{\mathrm{ns}}$ & $0,192^{\mathrm{ns}}$ & 34,6 \\
\hline $\mathrm{AF}^{(5)}(\%)$ & 0,85 & $0,7 \mathrm{~b}$ & $1,0 \mathrm{a}$ & $0,001^{*}$ & $0,001^{*}$ & $0,001^{*}$ & 33,3 \\
\hline
\end{tabular}

${ }^{(1)}$ Tukey's test at $5 \%$ probability; Means followed by lowercase letters in the row indicate difference between sexes; ns Nonsignificant; *Significant at $5 \%$ probability; ${ }^{(2)}$ Coefficient of variation; ${ }^{(3)}$ Carcass yield; ${ }^{(4)}$ Edible viscera $($ liver + heart + gizzard $) ;{ }^{(5)}$ Abdominal fat. 
Table 4. Live weight and characteristics of carcass and main cuts of broiler chickens of different genotypes raised under an alternative system.

\begin{tabular}{cccccccc}
\hline \multirow{2}{*}{ Variable } & Sex & \multicolumn{7}{c}{ Genotype } \\
\cline { 2 - 7 } & & NHS & JGB & RIR & IG & IGxNHS & IGxJBG \\
\hline \multirow{2}{*}{ Live Weight } & Male & $2,2 \mathrm{aA}$ & $2,1 \mathrm{aAB}$ & $1,8 \mathrm{aC}$ & $1,9 \mathrm{aBC}$ & $2,2 \mathrm{aA}$ & $2,2 \mathrm{aA}$ \\
$(\mathrm{Kg})$ & Female & $1,5 \mathrm{bAB}$ & $1,6 \mathrm{bAB}$ & $1,4 \mathrm{bB}$ & $1,7 \mathrm{aA}$ & $1,6 \mathrm{bAB}$ & $1,7 \mathrm{bA}$ \\
& Average & $1,9 \mathrm{AB}$ & $1,9 \mathrm{AB}$ & $1,6 \mathrm{C}$ & $1,8 \mathrm{~B}$ & $1,9 \mathrm{AB}$ & $2,0 \mathrm{~A}$ \\
\hline \multirow{2}{*}{ Carcass Wei- } & Male & $1,6 \mathrm{aA}$ & $1,5 \mathrm{aAB}$ & $1,3 \mathrm{aB}$ & $1,3 \mathrm{aB}$ & $1,7 \mathrm{aA}$ & $1,7 \mathrm{aA}$ \\
ght (Kg) & Female & $1,1 \mathrm{bAB}$ & $1,2 \mathrm{bAB}$ & $0,9 \mathrm{bB}$ & $1,3 \mathrm{aA}$ & $1,2 \mathrm{bAB}$ & $1,3 \mathrm{bA}$ \\
& Average & $1,4 \mathrm{AB}$ & $1,3 \mathrm{ABC}$ & $1,2 \mathrm{C}$ & $1,3 \mathrm{ABC}$ & $1,5 \mathrm{~A}$ & $1,5 \mathrm{~A}$ \\
\hline CY $^{(1)}(\%)$ & Average & $74,5 \mathrm{~A}$ & $72,2 \mathrm{~A}$ & $73,2 \mathrm{~A}$ & $74,7 \mathrm{~A}$ & $76,1 \mathrm{~A}$ & $76,3 \mathrm{~A}$ \\
& Male & $326,2 \mathrm{aAB}$ & $351,8 \mathrm{bA}$ & $274,7 \mathrm{aB}$ & $270,8 \mathrm{bB}$ & $373,0 \mathrm{aA}$ & $365,9 \mathrm{aA}$ \\
\multirow{2}{*}{ Breast $(\mathrm{g})$} & Female & $251,8 \mathrm{bBC}$ & $392,1 \mathrm{aAB}$ & $228,4 \mathrm{bC}$ & $322,9 \mathrm{aA}$ & $303,7 \mathrm{bAB}$ & $318,4 \mathrm{bA}$ \\
& Average & $288,9 \mathrm{CD}$ & $371,9 \mathrm{ABC}$ & $251,6 \mathrm{D}$ & $296,8 \mathrm{BC}$ & $338,3 \mathrm{AB}$ & $342,2 \mathrm{~A}$ \\
\hline Breast $(\%)$ & Average & $21,2 \mathrm{~B}$ & $24,4 \mathrm{~A}$ & $22,0 \mathrm{AB}$ & $22,4 \mathrm{AB}$ & $23,3 \mathrm{AB}$ & $22,8 \mathrm{AB}$ \\
\hline \multirow{2}{*}{ Leg $(\mathrm{g})$} & Male & $498,3 \mathrm{aA}$ & $482,2 \mathrm{aA}$ & $381,8 \mathrm{aB}$ & $405,4 \mathrm{aB}$ & $529,4 \mathrm{aA}$ & $549,6 \mathrm{aA}$ \\
& Female & $328,8 \mathrm{bAB}$ & $350,1 \mathrm{bAB}$ & $292,8 \mathrm{bB}$ & $381,3 \mathrm{aA}$ & $366,0 \mathrm{bAB}$ & $393,8 \mathrm{bA}$ \\
& Average & $413,6 \mathrm{BC}$ & $416,1 \mathrm{BC}$ & $337,3 \mathrm{D}$ & $393,4 \mathrm{C}$ & $447,7 \mathrm{AB}$ & $471,7 \mathrm{~A}$ \\
\hline Leg $(\%)$ & Average & $29,9 \mathrm{~A}$ & $29,8 \mathrm{~A}$ & $29,3 \mathrm{~A}$ & $29,8 \mathrm{~A}$ & $29,5 \mathrm{~A}$ & $31,0 \mathrm{~A}$ \\
\hline
\end{tabular}

Values with different superscripts in the same row or column are statistically different according to the Tukey's test at $5 \%$ probability; means followed by lowercase letters in the column indicate the difference between sexes; means followed by uppercase letters in the row indicate the difference between genotypes. Namely: NHS - New Hampshire; JBG - Jersey Black Giant; RIR Rodhe Island Red; IG - Indigenous Giant; IG $\times$ NHS - F1 generation resulted from the cross between Indigenous Giant and New Hampshire; IG $\times$ JBG - F1 generation resulted from the cross between Indigenous Giant and Jersey Black Giant. ${ }^{(1)}$ Carcass yield.

An interaction between genotype and sex was observed for breast and leg meat weight (Table 3). In all genotypes, males presented the highest values for these characteristics, except for IG, in which no differences between sexes were found (Tables 5 and 6). Among males, crossbred broiler chickens $(\mathrm{IG} \times \mathrm{NHS}$ and $\mathrm{IG} \times \mathrm{JBG})$ presented the highest averages of breast meat weight when compared to RIR birds whereas similar values were found for the other genotypes. Among females, the genotypes IG and those from crosses $(\mathrm{IG} \times$ NHS and $\mathrm{IG} \times$ JBG) presented higher averages in relation to the genotypes NHS and RIR (Table 5).
Considering the leg meat weight, the crosses IG $\times$ NHS and $\mathrm{IG} \times \mathrm{JBG}$ presented the highest averages among males, differing from the genotype of origin IG (Table 6). This shows a muscular increment with crossbreeding. However, this effect was not observed among females since no difference was observed in leg meat weight among origin genotypes (NHS, JBG, and IG) and those from crosses ( $\mathrm{IG} \times$ NHS and $\mathrm{IG} \times \mathrm{JBG})$.

In general, crossbred broiler chickens $(\mathrm{IG} \times \mathrm{NHS}$ and $\mathrm{IG} \times \mathrm{JBG}$ ), regardless of sex, presented higher values of breast and leg meat weight (Tables 5 and 6). This behavior indicates a greater deposition of muscle tissue due to protein anabolism and hybrid vigor associated with the sexual category and crosses between breeds (GONZALES; SARTORI, 2002). 
Table 5. Weight and proportion of tissue constituents (meat, bone, and skin) of the breast of broiler chickens from different genotypes reared under an alternative system.

\begin{tabular}{|c|c|c|c|c|c|c|c|}
\hline \multirow{2}{*}{ Variable } & \multirow{2}{*}{ Sex } & \multicolumn{6}{|c|}{ Genotype } \\
\hline & & NHS & JBG & RIR & IG & IGxNHS & IGxJBG \\
\hline \multirow{3}{*}{ Meat (g) } & Male & $205,4 \mathrm{aAB}$ & $226,8 \mathrm{aAB}$ & $188,9 \mathrm{aB}$ & $203,3 \mathrm{aAB}$ & $250,2 \mathrm{aA}$ & $250,9 \mathrm{aA}$ \\
\hline & Female & $154,5 \mathrm{bB}$ & $192,3 \mathrm{bAB}$ & $150,8 \mathrm{bB}$ & $235,4 \mathrm{aA}$ & $210,4 \mathrm{bA}$ & $216,0 \mathrm{bA}$ \\
\hline & Average & $179,9 \mathrm{BC}$ & $209,6 \mathrm{AB}$ & $169,8 \mathrm{C}$ & $219,4 \mathrm{~A}$ & $230,3 \mathrm{~A}$ & $233,4 \mathrm{~A}$ \\
\hline Meat (\%) & Average & $65,0 \mathrm{C}$ & $66,9 \mathrm{BC}$ & $66,6 \mathrm{BC}$ & $71,2 \mathrm{~A}$ & $68,9 \mathrm{AB}$ & $68,3 \mathrm{AB}$ \\
\hline Bone (g) & Average & $65,8 \mathrm{AB}$ & $71,2 \mathrm{AB}$ & $60,2 B$ & $64,0 \mathrm{~B}$ & $72,2 \mathrm{AB}$ & $77,7 \mathrm{~A}$ \\
\hline Bone $(\%)$ & Average & $23,9 \mathrm{~A}$ & $22,8 \mathrm{~A}$ & $23,4 \mathrm{~A}$ & $21,3 \mathrm{~A}$ & $21,6 \mathrm{~A}$ & $22,6 \mathrm{~A}$ \\
\hline \multirow{2}{*}{ Skin (g) } & Average & $30,1 \mathrm{AB}$ & $32,1 \mathrm{~A}$ & $25,4 \mathrm{AB}$ & $23,2 \mathrm{~B}$ & $31,9 \mathrm{~A}$ & $29,2 \mathrm{~A}$ \\
\hline & Male & $9,6 \mathrm{bA}$ & $9,8 \mathrm{aA}$ & $9,4 \mathrm{aA}$ & $8,0 \mathrm{aA}$ & $9,3 \mathrm{aA}$ & $9,1 \mathrm{aA}$ \\
\hline \multirow[t]{2}{*}{ Skin $(\%)$} & Female & $12,7 \mathrm{aA}$ & $10,8 \mathrm{aAB}$ & $10,5 \mathrm{aAB}$ & $7,1 \mathrm{aC}$ & $9,7 \mathrm{aB}$ & $9,1 \mathrm{aBC}$ \\
\hline & Average & $11,2 \mathrm{~A}$ & $10,3 \mathrm{AB}$ & 9,9AB & $7,6 \mathrm{C}$ & $9,5 \mathrm{~B}$ & $9,1 \mathrm{BC}$ \\
\hline Maet/bone & Average & $2,7 \mathrm{~B}$ & $3,1 \mathrm{AB}$ & $2,9 \mathrm{AB}$ & $3,4 \mathrm{~A}$ & $3,2 \mathrm{AB}$ & $3,1 \mathrm{AB}$ \\
\hline
\end{tabular}

Values with different superscripts in the same row or column are statistically different according to the Tukey's test at $5 \%$ probability; means followed by lowercase letters $(\mathrm{ab})$ in the column indicate the difference between sexes; means followed by uppercase letters $(\mathrm{AB})$ in the row indicate the difference between genotypes. Namely: NHS - New Hampshire; JBG - Jersey Black Giant; RIR - Rodhe Island Red; IG - Indigenous Giant; IG $\times$ NHS - F1 generation resulted from the cross between Indigenous Giant and New Hampshire; IG $\times$ JBG - F1 generation resulted from the cross between Indigenous Giant and Jersey Black Giant.

A significant genotype effect was observed in the proportion of breast meat (Table 3). In this sense, the genotype IG presented the highest average value for this characteristic, which was similar to the values found for crosses $(\mathrm{IG} \times \mathrm{NHS}$ and $\mathrm{IG} \times \mathrm{JBG})$ (Table 5). In fact, IG broiler chickens present a large size and hence a higher proportion of breast meat. Due to the heterosis effect, broiler chickens from the $\mathrm{F} 1$ generation $(\mathrm{IG} \times \mathrm{NHS}$ and $\mathrm{IG} \times \mathrm{JBG})$ also presented similar proportions. On the other hand, the genotype IG presented the lowest proportion of leg meat, but its crossing with the genotype JBG $(\mathrm{IG} \times \mathrm{JBG})$ provided a significant improvement of this characteristic, with an average higher than that found for the genotype IG, but similar to the others genotypes (Table 6).
Broiler chickens from crosses between the genotypes IG and JBG $(\mathrm{IG} \times \mathrm{JBG})$ presented a higher value of breastbone weight when compared to the genotypes RIR and IG, but similar to the other genotypes (Table 5). Similar results were obtained for legs in which the broiler chickens of this genotype presented the highest average of bone weight, however similar to IG and broiler chickens from a cross between IG and NHS (IG $\times$ NHS ) (Table 6). Regarding the proportion of breastbone, no difference was observed between genotypes (Table 5). However, the genotype IG presented a higher value for the proportion of leg bone when compared to the other genotypes (Table 6), which confirms its breed pattern, i.e. a leg with long length and a well-developed bone structure (ABCIG, 2016). 
Table 6. Weight and proportion of tissue constituents (meat, bone, and skin) of the leg of broiler chickens from different genotypes reared under an alternative system.

\begin{tabular}{cccccccc}
\hline \multirow{2}{*}{ Variable } & \multirow{2}{*}{ Sex } & \multicolumn{6}{c}{ Genotype } \\
\cline { 3 - 7 } & Male & $293,0 \mathrm{aABC}$ & $310,5 \mathrm{aAB}$ & $260,6 \mathrm{aBC}$ & $247,4 \mathrm{aC}$ & $340,1 \mathrm{aA}$ & $348,8 \mathrm{aA}$ \\
\multirow{3}{*}{ Meat $(\mathrm{g})$} & Female & $204,5 \mathrm{bA}$ & $224,6 \mathrm{bA}$ & $188,2 \mathrm{bB}$ & $249,4 \mathrm{aA}$ & $237,2 \mathrm{bA}$ & $260,4 \mathrm{bA}$ \\
& Average & $248,8 \mathrm{BC}$ & $267,6 \mathrm{AB}$ & $224,4 \mathrm{C}$ & $248,4 \mathrm{BC}$ & $288,6 \mathrm{AB}$ & $304,6 \mathrm{~A}$ \\
\multirow{2}{*}{ Meat (\%) } & Average & $64,6 \mathrm{AB}$ & $65,5 \mathrm{AB}$ & $65,2 \mathrm{AB}$ & $63,6 \mathrm{~B}$ & $65,8 \mathrm{AB}$ & $66,3 \mathrm{~A}$ \\
Bone (g) & Average & $97,6 \mathrm{BC}$ & $101,3 \mathrm{BC}$ & $88,6 \mathrm{C}$ & $112,0 \mathrm{AB}$ & $113,4 \mathrm{AB}$ & $121,5 \mathrm{~A}$ \\
Bone (\%) & Average & $25,1 \mathrm{~B}$ & $24,7 \mathrm{~B}$ & $25,4 \mathrm{~B}$ & $28,5 \mathrm{~A}$ & $25,7 \mathrm{~B}$ & $26,3 \mathrm{~B}$ \\
Skin (g) & Average & $39,0 \mathrm{~A}$ & $39,5 \mathrm{~A}$ & $31,8 \mathrm{BC}$ & $30,5 \mathrm{C}$ & $37,0 \mathrm{AB}$ & $34,0 \mathrm{ABC}$ \\
& Male & $9,2 \mathrm{bA}$ & $9,2 \mathrm{bA}$ & $8,7 \mathrm{bAB}$ & $7,7 \mathrm{aBC}$ & $8,1 \mathrm{aABC}$ & $7,2 \mathrm{aC}$ \\
\multirow{2}{*}{ Skin (\%) } & Female & $11,4 \mathrm{aA}$ & $10,4 \mathrm{aAB}$ & $10,0 \mathrm{aBC}$ & $8,0 \mathrm{aD}$ & $8,8 \mathrm{aCD}$ & $7,7 \mathrm{aD}$ \\
& Average & $10,3 \mathrm{~A}$ & $9,8 \mathrm{AB}$ & $9,3 \mathrm{~B}$ & $7,8 \mathrm{CD}$ & $8,5 \mathrm{C}$ & $7,4 \mathrm{D}$ \\
\multirow{2}{*}{ Maet/bone } & Average & $2,6 \mathrm{~A}$ & $2,7 \mathrm{~A}$ & $2,6 \mathrm{~A}$ & $2,2 \mathrm{~B}$ & $2,6 \mathrm{~A}$ & $2,5 \mathrm{AB}$ \\
\hline
\end{tabular}

Values with different superscripts in the same row or column are statistically different according to the Tukey's test at 5\% probability; means followed by lowercase letters ( $\mathrm{ab}$ ) in the column indicate the difference between sexes; means followed by uppercase letters $(\mathrm{AB})$ in the row indicate the difference between genotypes. Namely: NHS - New Hampshire; JBG - Jersey Black Giant; RIR Rodhe Island Red; IG - Indigenous Giant; IG $\times$ NHS - F1 generation resulted from the cross between Indigenous Giant and New Hampshire; IG $\times$ JBG - F1 generation resulted from the cross between Indigenous Giant and Jersey Black Giant.

The variation in the amount of certain tissue will influence the proportion of other tissues and, in situations of similar weight, birds with a higher amount of muscle tissue will indicate individuals with a higher potential for growth and meat production (SOGUNLE et al., 2013). This was also observed for females that presented a higher proportion of meat and a lower proportion of bone in the legs (Table 3). Males presented a higher weight and proportion of bone for both cuts (Table 3 ), which confirms their higher live weight and, consequently, a well-developed bone structure (MITROVIC et al., 2011; DEL CASTILHO et al., 2013).

A difference between genotypes was observed for breast and leg skin weight (Table 3). In general, the genotype IG presented lower values for these characteristics, not differing from the genotypes RIR and NHS (breast skin weight) and RIR and IG $\times$ JBG (leg skin weight) (Tables 5 and 6). Regarding the proportion of skin, an interaction was observed between genotypeand sex for both cuts (Table 3). For breast, a difference was observed between sexes only for the genotype NHS, with higher values for females (Table 5). Among males, no difference was observed between genotypes for the proportion of skin. However, among females, the lowest value was found for the genotype IG, which was similar to the hybrid $\mathrm{IG} \times \mathrm{JBG}$.

Regarding the leg, a difference was observed for the proportion of skin between sexes only for the genotypes NHS, JBG, and RIR, with the females presenting the highest averages (Table 6). In general, the genotypes NHS and JBG presented higher values of the proportion of leg skin for both sexes. The differences in weight and proportion of skin would be related to the influence of steroid hormones, which exert effects in its different layers such as the hypoderm, causing an increase in thickness and weight due to an increased volume of adipocytes that invade the superficial fascia (ISOLA et al., 2013).

For meat to bone ratio in the breast, the genotype IG presented higher values when compared to those from the genotype NHS, but similar to the other genetic groups (Table 5). The lowest value for meat to bone ratio in the leg was observed for IG broiler chickens, but similar to IG $\times$ JBG (Table 6$)$. This behavior indicates that the tissue deposition rates 
were different between chickens and may occur independently between cuts. In addition, a better balance in relation to this proportion and tissue composition may be obtained by crosses between different breeds, aiming at achieving a maximum efficiency in muscle development.

Regarding sex, females presented better average values of meat to bone ratio for both cuts (Table 3). According to Gonzales and Sartori (2002), this behavior can be explained mainly by the characteristics of sexual dimorphism, in which females present a less-developed bone structure, which is evidenced by the low values of bone weight found in our study for females.

An interaction was observed between genotype and sex for wing and back weight (Table 3), in which males from all genotypes presented higher values, except for IG, which did not present differences between sexes (Table 7). Among males, the genotypes RIR and IG presented the lowest averages for these variables. Among females, on the other hand, similar results were found, with the genotype RIR presenting the lowest values of wing and back weight (Table 7). These differences between genotypes are due to differences in the tissue growth rates, i.e. even when broiler chickens are slaughtered at the same age, slower-growing broiler chickens present lower bone development (FARIA et al., 2010, 2011; SARICA et al., 2014). Thus, because wing and back are composed mostly of bone tissue, lesser-developing broiler chickens, such as those from the genotypes RIR and IG, tend to have these cuts less heavy. However, neither genotype nor sex effects were observed for wing nor back yields (Table 7).

Table 7. Characteristics of secondary cuts, weight, and yield of edible viscera and abdominal fat of broiler chickens from different genotypes reared under an alternative system.

\begin{tabular}{cccccccc}
\hline \multirow{2}{*}{ Variable } & \multirow{2}{*}{ Sex } & \multicolumn{7}{c}{ Genotype } \\
\cline { 3 - 7 } & & NHS & JBG & RIR & IG & IGxNHS & IGxJBG \\
\hline \multirow{2}{*}{ Wing $(\mathrm{g})$} & Male & $188,9 \mathrm{aAB}$ & $193,8 \mathrm{aAB}$ & $163,8 \mathrm{aC}$ & $167,0 \mathrm{aBC}$ & $204,4 \mathrm{aA}$ & $203,4 \mathrm{aA}$ \\
& Female & $142,7 \mathrm{bAB}$ & $144,5 \mathrm{bAB}$ & $127,7 \mathrm{bC}$ & $163,6 \mathrm{aA}$ & $147,6 \mathrm{bA}$ & $154,7 \mathrm{bA}$ \\
& Average & $165,8 \mathrm{AB}$ & $169,2 \mathrm{~A}$ & $145,7 \mathrm{~B}$ & $165,3 \mathrm{AB}$ & $175,9 \mathrm{~A}$ & $179,1 \mathrm{~A}$ \\
Wing $(\%)$ & Average & $12,1 \mathrm{~A}$ & $12,8 \mathrm{~A}$ & $12,7 \mathrm{~A}$ & $12,6 \mathrm{~A}$ & $12,0 \mathrm{~A}$ & $11,8 \mathrm{~A}$ \\
& Male & $282,8 \mathrm{aAB}$ & $278,2 \mathrm{aAB}$ & $234,8 \mathrm{aBC}$ & $213,4 \mathrm{aC}$ & $297,9 \mathrm{aA}$ & $304,4 \mathrm{aA}$ \\
$\mathrm{Back}(\mathrm{g})$ & Female & $211,1 \mathrm{bAB}$ & $206,9 \mathrm{bAB}$ & $167,3 \mathrm{bB}$ & $225,1 \mathrm{aA}$ & $217,5 \mathrm{bA}$ & $220,4 \mathrm{bA}$ \\
& Average & $247,0 \mathrm{AB}$ & $242,5 \mathrm{AB}$ & $201,1 \mathrm{C}$ & $219,3 \mathrm{BC}$ & $257,8 \mathrm{~A}$ & $262,4 \mathrm{~A}$ \\
$\mathrm{Back}(\%)$ & Average & $18,0 \mathrm{~A}$ & $18,4 \mathrm{~A}$ & $17,4 \mathrm{~A}$ & $16,6 \mathrm{~A}$ & $17,6 \mathrm{~A}$ & $17,2 \mathrm{~A}$ \\
& Male & $103,1 \mathrm{aA}$ & $97,7 \mathrm{aA}$ & $96,5 \mathrm{aA}$ & $91,1 \mathrm{aA}$ & $94,9 \mathrm{aA}$ & $102,1 \mathrm{aA}$ \\
$\mathrm{EV}^{(1)}(\mathrm{g})$ & Female & $72,8 \mathrm{bA}$ & $82,2 \mathrm{bA}$ & $80,1 \mathrm{bA}$ & $79,4 \mathrm{bA}$ & $75,9 \mathrm{bA}$ & $79,2 \mathrm{bA}$ \\
& Average & $87,9 \mathrm{~A}$ & $89,9 \mathrm{~A}$ & $88,3 \mathrm{~A}$ & $85,3 \mathrm{~A}$ & $85,4 \mathrm{~A}$ & $90,6 \mathrm{~A}$ \\
$\mathrm{EV}^{(1)}(\%)$ & Average & $6,4 \mathrm{BC}$ & $6,8 \mathrm{~B}$ & $7,7 \mathrm{~A}$ & $6,5 \mathrm{BC}$ & $5,9 \mathrm{C}$ & $5,9 \mathrm{C}$ \\
$\mathrm{AF}^{(2)}(\mathrm{g})$ & Average & $31,4 \mathrm{~A}$ & $29,4 \mathrm{~A}$ & $10,2 \mathrm{BC}$ & $2,3 \mathrm{D}$ & $4,7 \mathrm{CD}$ & $13,0 \mathrm{~B}$ \\
& Male & $1,2 \mathrm{bA}$ & $1,3 \mathrm{bA}$ & $0,6 \mathrm{aB}$ & $0,1 \mathrm{aC}$ & $0,2 \mathrm{aBC}$ & $0,6 \mathrm{aB}$ \\
$\mathrm{AF}^{(2)}(\%)$ & Female & $2,4 \mathrm{aA}$ & $1,9 \mathrm{aA}$ & $0,7 \mathrm{aBC}$ & $0,2 \mathrm{aC}$ & $0,4 \mathrm{aBC}$ & $0,7 \mathrm{aB}$ \\
& Average & $1,8 \mathrm{~A}$ & $1,6 \mathrm{~A}$ & $0,7 \mathrm{~B}$ & $0,1 \mathrm{C}$ & $0,3 \mathrm{C}$ & $0,7 \mathrm{~B}$ \\
\hline
\end{tabular}

Values with different superscripts in the same row or column are statistically different according to the Tukey's test at $5 \%$ probability; means followed by lowercase letters $(\mathrm{ab})$ in the column indicate the difference between sexes; means followed by uppercase letters (AB) in the row indicate the difference between genotypes. Namely: NHS - New Hampshire; JBG - Jersey Black Giant; RIR Rodhe Island Red; IG - Indigenous Giant; IG $\times$ NHS - F1 generation resulted from the cross between Indigenous Giant and New Hampshire; IG $\times$ JBG - F1 generation resulted from the cross between Indigenous Giant and Jersey Black Giant. ${ }^{(1)}$ Edible viscera;

${ }^{(2)}$ Abdominal fat. 
Regarding the weight of edible viscera, an interaction was observed between genotype and sex (Table 3), with males of all genotypes showing higher values (Table 7). In fact, males present a greater food digestion efficiency since they have a higher body weight, making the organs involved in this process, such as liver and gizzard, to be more developed (MITROVIC et al., 2011). For edible viscera yield, a significant effect was observed only for genotype (Table 3), with the genotype RIR presenting higher yield when compared to other breeds (Table 7). This is probably due to their lower average carcass weight (Table 4), which may have increased the proportion and, consequently, the yield of edible viscera.

An interaction was observed between genotype and sex for abdominal fat yield (Table 3). In this sense, a difference between sexes was observed only for NHS and JBG, with females presenting higher values (Table 7). Santos et al. (2005), Faria et al. (2011), Mitrovic et al. (2011), and Sarica et al. (2014) observed a higher average of abdominal fat yield in females, which is probably due to differences in growth rates between sexes. Because females present earlier maturity, they deposit a greater amount of fat in the carcass, mainly in the abdominal region (GONZALES; SARTORI, 2002).

For both sexes, the genotypes NHS and JBG presented higher abdominal fat yields (Table 7). An effect of genotype was observed on abdominal fat weight (Table 3), with the genotypes NHS and JBG showing the highest averages (Table 7). The fastest-growing broiler chickens achieved a peak of muscle growth and physiological maturity earlier than slow-growing broiler chickens. As a result, a growing portion of diet energy is converted into adipose tissue, which will accumulate first in the abdominal region (GONZALES; SARTORI, 2002). Thus, the fastest-growing genotypes, such as NHS and JBG, tend to have a higher proportion of abdominal fat due to the lipid deposition be earlier in these broiler chickens.

\section{Conclusions}

The genotypes resulting from the crossing of different breeds of broiler chickens provided better results for meat production, with a higher growth potential, carcass characteristics, and muscular portion of both cuts.

In the production of chicken meat under an alternative system, females demonstrated a higher breast yield and a higher amount of meat in the leg despite producing lighter carcasses.

\section{References}

ALBINO, L. F. T.; TAVERNARI, F. C.; VIEIRA, R.A.; NERY, L.R. Criação de frango e galinha caipira, sistema alternativo de criação de aves. In: ALBINO, L. F. T.; TAVERNARI, F. C.; VIEIRA, R. A.; NERY, L. R. (Ed.). Aves mais indicadas. Viçosa: Aprenda Fácil, 2014. p. 2138.

ASSOCIAÇÃO BRASILEIRA DOS CRIADORES DE INDIO GIGANTE - ABCIG. Manual do criador de Índio Gigante. Belém: Ancrib, 2016. Disponível em: <http:// abcig.com.br/manual_do_criador_indio__ gigante.>. Acesso em: 15 maio $201 \overline{6}$.

DEL CASTILHO, C. C.; SANTOS, T. T.; RODRIGUES, C. A. F.; TORRES FILHO, R. A. Effects of sex and genotype on performance and yield characteristics of free range broiler chickens. Arquivo Brasileiro de Medicina Veterinária e Zootecnia, Belo Horizonte, v. 65, n. 5, p. 1483-1490, 2013. Disponível em: <http://www.scielo. br/pdf/abmvz/v65n5/a29v65n5.pdf >. Acesso em: $23 \mathrm{fev}$. 2016.

FARIA，P. B.; BRESSAN, M. C.; SOUZA, X. R.; ROSSATO, L. V.; BOTEGA L. M. G.; GAMA L. T. Carcass and parts yield of broilers reared under a semiextensive system. Revista Brasileira de Ciência Avícola / Brazilian Journal of Poultry Science, Campinas, v. 12, n. 3, p. 153-159, 2010. Disponível em: <http://www.scielo. br/pdf/rbca/v12n3/03.pdf $>$. Acesso em: 21 mar. 2016.

FARIA, P. B.; VIEIRA, J. O.; SILVA, J. N.; RODRIGUES, A. Q.; SOUZA, X. R.; SANTOS, F. R.; PEREIRA, A. A. Performance and carcass characteristics of alternative broiler chickens fed diets containing alternative foods. Revista Brasileira de Ciência Avícola / Brazilian Journal of Poultry Science, Campinas, v. 13, n. 3, p. 113-118, 2011. Disponível em: <http://www.scielo.br/pdf/rbca/ v13n3/09.pdf>. Acesso em: 21 mar. 2016. 
GONZALES, E.; BUYSE, J.; TAKITA, T. S.; SARTORI, J. R.; DECUYPERE, E. Metabolic disturbances in male broilers of different strains. 1. Performance, mortality and right ventricular hypertrophy. Poultry Science, Champaign, v. 77, n. 11, p. 1646-1653, 1998. Disponível em: $\quad<$ https://academic.oup.com/ps/article-lookup/ doi/10.1093/ps/77.11.1646>. Acesso em: 25 jun. 2016.

GONZALES, E.; SARTORI, J. R. Crescimento e metabolismo muscular. In: MACARI, M.; FURLAN, R. L; GONZALES, E. (Ed.). Fisiologia aviária aplicada a frangos de corte. Jaboticabal: FUNEP/UNESP, 2002. p. 279-297.

ISOLA, J. G. M. P.; MORAES, P. C.; RAHAL, S. C.; MACHADO, M. R. F. Morfologia, ultraestrutura e morfometria do tegumento da paca (Cuniculus paca Linnaeus, 1766) criada em cativeiro. Pesquisa Veterinária Brasileira, Seropédica, v. 33, n. 5, p. 674682, 2013. Disponível em: <http://repositorio.unesp.br /bitstream/handle/11449/75290/2-s2.0-84880783928. sequence $=1 \&$ is Allowed $=\mathrm{y}>$. Acesso em: 20 maio 2016 .

KESSLER, A. M.; SNIZEK, P. N.; BRUGALLI, I. Manipulação da quantidade de gordura na carcaça de frangos. In: FUNDAÇÃO DE CIÊNCIA E TECNOLOGIA AVÍCOLAS, 1., 2000, Campinas. Anais... Campinas: Fundação Apinco de Ciência e Tecnologia Avícolas, Campinas, 2000. p. 107-133.

MADEIRA, L. A.; SARTORI, J. R.; ARAUJO, P. C.; PIZZOLANTE, C. C.; SALDANHA, E. S. P. B.; PEZZATO, A. C. Morfologia das fibras musculares esqueléticas de frangos de corte de diferentes linhagens criados em sistema de confinamento e semi confinamento. Revista Brasileira de Zootecnia, Viçosa, v. 35, n. 6, p. 2322-2332, 2006. Disponível em: <http://www.scielo.br/ pdf/\%0D/rbz/v35n6/18.pdf $>$. Acesso em: 13 abr. 2016.

MIKULSKI, D.; CELEJ, J.; JANKOWSKI, J.; MAJEWSKA, T.; MIKULSKAET, M. Growth performance, carcass traits and meat quality of slower-growing and fast-growing chickens raised with and without outdoor access. Asian-Australasian Journal Animal Science, Seoul, v. 24, n. 10, p. 14071416, 2011. Disponível em: <http://ocean.kisti.re.kr/ downfile/volume/aaaaps/E1DMBP/2011/v24n10/ E1DMBP_2011_v24n10_1407.pdf>. Acesso em: 14 abr. 2016.

MITROVIC, S.; BOGOSAVLJEVIC-BOSKOVIC, S.; STANISIC, G.; DJERMANOVIC, V.; DOSKOVIC, V.; RAKONJAC, S. Carcass characteristics of two strains of native broilers (White Naked Neck and Black Svrljig) fattened under a semi-intensive system. African Journal of Biotechnology, Nairobi, v. 10, n. 70, p. 15813-15818, 2011. Disponível em: <http://search.proquest.com/ openview/ ba1d6bef9420f92a212ba2d7ce5dca30/1?pq origsite $=$ gscholar $\& \mathrm{cbl}=1006374>$. Acesso em: 14 abr. 2016.

SANTOS, A. L.; SAKOMURA, N. K.; FREITAS, E. R.; FORTES, C. M. L.; CARRILHO, E. N. V. M.; FERNANDES, J. B. K. Estudo do crescimento, desempenho, rendimento de carcaça e qualidade de carne de três linhagens de frango de corte. Revista Brasileira de Zootecnia, Viçosa, v. 34, n. 5, p. 15891598, 2005. Disponível em: <http://www.scielo.br/pdf/ rbz/v34n5/26640.pdf $>$. Acesso em: 25 abr. 2016.

SARICA, M.; YAMAK, U. S.; TURHAN, S.; BOZ, M. A.; SARICAOGLU, F. T.; ALTOP, A. Comparing slow-growing chickens produced by two- and threeway crossings with commercial genotypes. 2. Carcass quality and blood parameters. European Poultry Science, Stuttgart, v. 14, n. 1, p. 2014-2030, 2014. Disponível em: $<$ https://www.researchgate.net/profile/Furkan_Turker/ publication/262635967 Comparing slowgrowing chickens produced by twoand threeway crossings with commercial genotypes 2 Carcass quality and blood parameters/links/0deec53848776de1eb000000/ Comparing-slow-growing-chickens-produced-by-two and-three-way-crossings-with-commercial-genotypes-2Carcass-quality-and-blood-parameters.pdf $>$. Acesso em: 15 abr. 2016.

SOGUNLE, O. M.; OLANIYI, O. A.; EGBEYALE, L. T.; AKINOLA, O. S.; SHITTU, T. A.; ABIOLA, S. S.; LADOKUN, A. O.; SOBAYO, R. A. Free range and deep litter poultry production systems: effect on performance, carcass yield and meat composition of cockerel chickens. Tropical Animal Health and Production, Edinburgh, v. 45 , n. 1 , p. $281-288,2013$. Disponível em: <https:// link.springer.com/article/ 10.1007/s11250-012-0213-2>. Acesso em: 16 abr. 2016.

VELOSO, R. C.; PIRES, A. V.; TORRES FILHO, R. A.; PINHEIRO, S. R. F.; WINKELSTROTER, L. K.; ALCÂNTARA, D. C.; CRUZ, C. C. D. C. S. Parâmetros de desempenho e carcaça de genótipos de frangos tipo caipira. Arquivo Brasileiro de Medicina Veterinária e Zootecnia, Belo Horizonte, v. 66, n. 4, p. 1251-1259, 2014.Disponível em: <http://www.scielo.br/pdf/abmvz/ v66n4/0102-0935-abmvz-66-04-01251.pdf>. Acesso em: 02 maio 2016. 